DOI: $\underline{10.34305 / g e m i c . v 1 i 1.315}$

\title{
THE EFFECT OF AUDIO VISUAL AND WEBTOON EXPLANATION TO KNOWLEDGE AND ATTITUDE ABOUT THE THREE BASIC THREATS OF ADOLESCENT REPRODUCTIVE HEALTH (TRIAD KRR) ON STUDENTS OF SMAN 8 CIREBON CITY, 2021
}

\author{
Diyah Sri Yuhandini, Nadhifatun Khulaidah \\ Poltekkes Kemenkes Tasikmalaya \\ diyahsriyuhandini80@gmail.com
}

\begin{abstract}
The problem of adolescent reproductive health in Indonesia is about sexuality, HIV / AIDS and drugs. The problem occurs due to low knowledge of the TRIAD KRR which will affect the attitudes that adolescents will take in relation to the TRIAD KRR. The low level of knowledge occurs due to the lack of education that adolescents get about TRIAD KRR. The aim of this study was to find out the effect of providing counseling through audio-visual and webtoon on increasing knowledge and attitudes about the three basic threats to adolescent reproductive health (TRIAD KRR). This research is a quasi experimental study using a two groups pretest-posttest design approach. The research sample was students of SMAN 8 Cirebon City. The data analysis used was univariate and bivariate analysis using the Wilxocon test, paired $\mathrm{t}$ test and the Man-witney test. The measuring instrument used is a questionnaire. The analysis of the median pretest obtained for knowledge in the audiovisual group was 8.0000 and the posttest was 11,000 . In the attitude, the median value for pretest was 36.00 and posttest was 37.00. Bivariate analysis in the audio-visual group, both knowledge and attitude, obtained $\mathrm{p}$ value $0.000(<0.05)$. In the knowledge of the webtoon group, the $\mathrm{p}$ value was $0.000(<0.05)$ and for the attitude, the p value was $0.350(>0.05)$. Differences in knowledge of audio visual media with webtoon obtained $\mathrm{p}$ value of 0.411 and for attitude that is 0.033 . There is no significant difference in knowledge through audio-visual media and webtoon but in attitude there is a difference.
\end{abstract}

Keywords : knowledge, attitude, sexuality 


\section{DOI: $\underline{10.34305 / g e m i c . v 1 i 1.315}$}

\section{Introduction}

The results of data research from the $\mathrm{BKKBN}$ regarding the incidence of adolescent cases in Indonesia in 2019, 48 out of 1000 teenagers in Indonesia experienced pregnancies outside of marriage. So it can be concluded that the incidence of such cases in Indonesia often increases by more than 500 cases every year.

Based on data from the Ministry of Health of the Republic of Indonesia (Kemenkes RI) which was published through Public Info in 2019 amount of Indonesian people suffering from HIV/AIDS reached 349,883 thousand people. Then in 2020, according to a report by the Directorate General of $\mathrm{P} 2 \mathrm{P}$ of the Indonesian Ministry of Health, the cumulative cases of HIV / AIDS in Indonesia have reached 500,000 thousand people.

In 2020 the Head of the National Anti Narcotics Agency Commissioner General of Police Heru Winarko said, narcotics abuse among teenagers was increasing, namely by $24-28 \%$ of teenagers who used narcotics.

According to the Directorate of Youth Resilience Development (2018), adolescence is a transitional age, the search for identity is accompanied by a great sense of youth curiosity, reinforced by increasingly sophisticated flows of technology and information causing adolescents to have unhealthy behavior and are at risk of being exposed to the Three Basic Threats of Reproductive Health (TRIAD KRR).

Adolescence is a period of change from childhood to adulthood, developing romantic feelings, and sexual experimentation, in the cycle of life, adolescence is a golden age. Teens begin to be able to think abstractly, criticize, and want to know new things. If not based on sufficient knowledge, adolescents can try new things related to reproductive health and can have a negative impact (Prabandari, 2018) .

The unavailability of adequate information about KRR forces teenagers to seek access to this information and conduct their own exploration, especially through the media. Promotion of reproductive health in adolescents is often connoted as sex education where most Indonesian people are still taboo about this.

The low of knowledge an adolescents about adolescent reproductive health will affect the attitudes that adolescents will take regarding adolescent 
reproductive health. The impact if not given education about adolescent reproductive health is easier to carry out risky sexual behavior which will cause reproductive health problems such as unwanted pregnancy (KTD), abortion and IMS (Nilasari, 2019).

According to M Basyarudin Usman, media is something that transmits messages and can stimulate the thoughts, feelings and desires of the audience (students) so that the learning process can occur in him. According to Burhan (2016), the level of effectiveness of learning through audio is only able to absorb $10-25 \%$, through visual only $25-55 \%$, then for audio-visual itself it reaches $55-80 \%$ and is participatory (role play, case studies and practice). up to 80 $90 \%$.

In accordance with the research conducted by Telly Katarina and Yuliana (2018) on the research title The Effect of Reproductive Health Education through Audio Visual with the Results of Knowledge After Counseling on Adolescents at SMA Negeri 2 Pontianak said that there was an influence between reproductive health education through audio-visual and the results of knowledge (Katharina \& Yuliana, 2018).
Likewise, the results of research conducted by Agustin Wahyu Prabandari (2018) on the research title The Effect of Counseling with Video Media and Booklets on Adolescent Reproductive Health Knowledge Levels at SMK 2 Muhammadiyah Bantul said that there was an effect after being given counseling either through video media or booklets (Prabandari, 2018).

Based on the results of a preliminary study of class $\mathrm{X}$ students at SMAN 8 Cirebon City with a total of 47 students through a questionnaire about TRIAD KRR, it was found that $80.4 \%$ of students did not really understand the knowledge of sexuality, only $41.3 \%$ who understand about HIV / AIDS and as much as $52.2 \%$ of them who understand about drugs.

In 2018 there was counseling on adolescent reproductive health for representatives of class $\mathrm{X}$ and class $\mathrm{XI}$ students. The counseling was carried out using the lecture and question and answer method. From 47 people during the preliminary study, who filled out the attitude questionnaire there were $70.2 \%$ of the students who answered agreed to conduct counseling on adolescent reproductive health in schools. So the 
researchers decided to re-do the counseling on the three basic threats to adolescent reproductive health (TRIAD KRR) with a new method, namely by using audio-visual media and webtoons.

The existence of counseling on the three basic threats to adolescent reproductive health (TRIAD KRR) by selecting the right method is expected to increase knowledge and attitudes about TRIAD KRR and become an effort to prevent unwanted pregnancy, HIV / AIDS cases and drug abuse incidents. illicit drugs (NAPZA). This makes researchers interested in conducting further research on the effect of audio-visual and webtoon extension on knowledge and attitudes regarding the three basic threats to reproductive health (TRIAD KRR) at SMAN 8 Cirebon City.

\section{Method}

This research is a design quasi experimental study with a two-group pretest-posttest design approach, where the research was conducted at SMAN 8 Cirebon City which was conducted in February - March 2021. The population in this study were students of class XI, amounting to 309 people, the sample was taken by simple random sampling technique.

Inclusion criteria are willing to be respondents, students who have a cell phone technology device (whatsapp), students who have quotas or are connected to the internet, respondents who follow the research process to completion. Exclusion criteria are respondents who are sick or there is no quota when collecting data, respondents who cannot follow the research process to completion.

The instrument in this study was a questionnaire from Sri Rezeki, 2015 with closed questions, namely 15 questions for knowledge and 10 questions for attitudes regarding the three basic threats to adolescent reproductive health (TRIAD KRR).

Data analysis to be carried out in this study is univariate and bivariate analysis with the Wilxocon test, paired ttest and the Mann-Whitney test.

\section{Result}

Univariate Analysis 
DOI: $\underline{10.34305 / g e m i c . v 1 i 1.315}$

Table 1. Median knowledge on audio visual

\begin{tabular}{lllll}
\hline & Min & Max & SD & Median \\
\hline Pre Test & 0 & 12 & 2.85409 & 8.0000 \\
\hline Post Test & 4 & 13 & 2.21722 & 11.0000 \\
\hline
\end{tabular}

The results of the analysis showed that the median value of knowledge about TRIAD KRR before being given audiovisual intervention was 8.0000 with a standard deviation of 2.85409. The lowest score is 0 and the highest score is 12 out of a total score of 15 questions. The result of the median value after being given the audio visual intervention was 11,000 with a standard deviation of 2.21722 . The lowest score is 4 and the highest is 13 .

Table 2. Median attitude on audio visual

\begin{tabular}{lllll}
\hline & Min & Max & SD & Median \\
\hline Pre Test & 29 & 43 & 3.973 & 37.00 \\
\hline Post Test & 29 & 44 & 3.678 & 39.00 \\
\hline
\end{tabular}

The results of the analysis showed that the median value of the attitude about TRIAD KRR before being given audiovisual intervention was 37.00 with a standard deviation of 3.973 . The lowest score was 29 and the highest score was 43 from a total score of 10 questions. The result of the median value after being given audio-visual intervention was 39.00 with a standard deviation of 3.678. The lowest value is 29 and the highest is 44 .

Table 3. Median knowledge on webtoon

\begin{tabular}{lllll}
\hline & Min & Max & SD & Median \\
\hline Pre Test & 0 & 12 & 3.14469 & 9.0000 \\
\hline Post Test & 4 & 13 & 2.09127 & 10.000 \\
\hline
\end{tabular}

The results of the analysis showed that the median value of knowledge about the KRR TRIAD before being given the webtoon intervention was 9.0000 with a standard deviation of 3.14469. The lowest score is 0 and the highest score is 12 out of a total score of 15 questions. The result of the median value after being given the webtoon intervention was 10,000 with a standard deviation of 2.09127. The lowest score is 4 and the highest is 13 . 
DOI: $\underline{10.34305 / g e m i c . v 1 i 1.315}$

Table 4. Median attitude on webtoon

\begin{tabular}{lllll}
\hline & Min & Max & SD & Median \\
\hline Pre Test & 21 & 45 & 5.342 & 36.00 \\
\hline Post Test & 29 & 45 & 4.26605 & 37.00 \\
\hline
\end{tabular}

The results of the analysis showed that the median value of attitudes about the TRIAD KRR before the webtoon intervention was given was 36.00 with a standard deviation of 5.342. The lowest score is 21 and the highest score is 45 from the total score of 10 questions. The median value after being given a webtoon intervention was 37.00 with a standard deviation of 4.26605 . The lowest score is 29 and the highest is 45 .

Bivariate Analysis

Table 5. Wilxocon test on audio visual and webtoon

\begin{tabular}{lcc}
\hline & $\begin{array}{c}\text { Median } \\
(\text { min-max })\end{array}$ & $\boldsymbol{P}$ \\
\hline Pre test - post test knowledge audio visual & $8.0000(0-12)$ & 0.000 \\
\hline Pre test - post test attitude audio visual & $11.000(4-13)$ & 0.000 \\
\hline Pre test - post test knowledge webtoon & $37.00(29-43)$ & 0.000 \\
\hline
\end{tabular}

Based on the Wilcoxon test in the audio-visual group, both knowledge and attitude obtained a p value of $0.000(<0.05)$ so that there was a statistically significant difference before and after the audio visual intervention. While in the webtoon group for knowledge, a $\quad p$ value of 0.000 was obtained $(<0.05)$ so that statistically there was a significant difference before and after being given counseling with webtoon media.

Table 6. Paired t-test of attitude on webtoon

\begin{tabular}{lcc}
\hline & $\begin{array}{c}\text { Median } \\
(\text { min-max })\end{array}$ & P \\
\hline Pre test - post test attitude webtoon & $-.73(-2.3-.84)$ & 0.350 \\
\hline
\end{tabular}

Based on the paired t-test, it was found that the $\mathrm{p}$ value was $0.350(>0.05)$ so 
that statistically there was no significant through the webtoon media.

difference before and after the intervention

Table 7. Mann-whitney $U$ test of knowledge and attitude on audio visual and webtoon

\begin{tabular}{lc}
\hline & P value \\
\hline Pre Knowledge & 0.247 \\
\hline Post Knowledge & 0.411 \\
\hline Pre Attitude & 0.971 \\
\hline Post Attitude & 0.033 \\
\hline
\end{tabular}

Based on the Mann-Whitney U pretest test, the knowledge of audio visual and webtoon obtained the Asym.sig value or $p$ value $0.247>0.05$. If the $p$ value> the critical limit of 0.05 , there is no significant difference between the two groups. Then for the posttest value of audio visual and webtoon knowledge, the Asym.sig value or $\mathrm{p}$ value is $0.411>0.05$. If the $\mathrm{p}$ value $>$ the critical limit of 0.05 , there is no significant difference between the two groups. As for the pretest value for audio-visual and webtoon attitudes, the Asym.sig value or $p$ value was $0.971>0.05$. If the $p$ value $>$ the critical limit of 0.05 , there is no significant difference between the two groups. For the audio-visual and webtoon posttest, the Asym.sig value or $\mathrm{p}$ value $0.033<0.05$ was obtained. If the p value < critical limit 0.05 , there is a significant difference between the two groups.
Univariate Analysis

Based on the results of the univariate analysis of the data that has been carried out, it shows that the median value before the audio-visual media intervention on knowledge is 8.0000 and after the intervention the median value is 11.00000 . Meanwhile, the median value before the intervention using webtoon media was 9.0000 and after the intervention was given the median value was 10.0000. Both treatments increased knowledge, but the difference in the median knowledge before and after in the experimental group, namely counseling with audio-visual media, the results were greater.

This is in accordance with the theory described by Burhan (2016), which states that the level of effectiveness of learning through audio is only able to absorb $10-25 \%$, through visuals is only 25 $55 \%$, then for audio-visual itself it reaches

\section{Discussion}




\section{DOI: $\underline{10.34305 / g e m i c . v 1 i 1.315}$}

$55-80 \%$ and participatory (role play, case studies and practice) reaches $80-90 \%$.

From the results of the univariate analysis using computer assistance, it can be seen that the median value before the intervention of audio visual media on attitudes is 37.00 and after being given the intervention the median value is 39.00 . Meanwhile, the median value before the intervention using webtoon media was 36.00 and after the intervention was given the median value was 37.00. Judging from the median value, both intervention through audio-visual media and webtoon media resulted in an increase in attitude.

Based on Ernawati's research (2018), adolescence is a transitional period between childhood and adulthood. Adolescents at this stage have not yet reached mental and social maturity, so they have to face many conflicting emotional and social pressures.

Many phenomena show that some adolescents do not know and understand about the three basic threats to adolescent reproductive health (TRIAD KRR), for example about the dangers of engaging in promiscuity which causes three basic threats to adolescent reproductive health. But parents in rural areas still think that talking about the TRIAD KRR to adolescents is still considered taboo.

This is supported by research by Ernawati (2018) that parents are not a source of information on TRIAD KRR for adolescents in the village, so that it will have an impact on the correctness of information obtained by adolescents.

\section{Bivariate Analysis}

Differences in students' knowledge and attitudes about TRIAD KRR through Audio Visual media.

The results in the Wilxocon test that had been carried out, obtained the Asym.sig value for the pretest-posttest results of audio-visual media knowledge, namely (0.000). As for attitude, the value of Asym.sig is (0.000). It can be concluded that there are differences in counseling using audio-visual media about TRIAD KRR on the knowledge and attitudes of respondents.

The results obtained from this study are in line with the research of Telly Khatarina and Yuliana with the title The Effect of Reproductive Health Counseling Through Audio Visual with Knowledge Results after Counseling for Adolescents at SMA Negeri 2 Pontianak in 2017 the results are that there is an effect of 


\section{DOI: $\underline{10.34305 / g e m i c . v 1 i 1.315}$}

reproductive health counseling through audio visual with the results of knowledge after explanation.

This research is in line with Lia Kurniasari's research (2017) which shows that knowledge can be influenced by the provision of video media because video can reflect a more effective absorption of information by using the senses of sight and hearing and can increase knowledge compared to using only the sense of sight.

This is in line with the results of research conducted by Yuce Nilasari (2019) with the title The Effect of Adolescent Reproductive Health Education with the Lecture Method on Knowledge and Attitudes in Vocational School 1 Poncol Students, Magetan Regency, that there is an effect of adolescent reproductive health education on knowledge.

According to the researcher's assumption, the similarity of attitudes is in accordance with the level of knowledge of the students, most of whom are quite knowledgeable about TRIAD KRR. If knowledge can change their negative attitude, then religious teachings can be used as a deterrent to these negative attitudes.

According to Maolinda (2012), a good attitude is also because students have received sufficient education from the environment and formal institutions. Experiences with family, friends, and society have equipped students to sort out what is good and what is bad for themselves. It is this separation of knowledge in the form of observation and experience that produces individual attitudes.

Differences in students' knowledge and attitudes about TRIAD KRR through Webtoon media.

The results of the Wilxocon test that had been carried out, for the pretest-posttest of knowledge on webtoon media, the Asym.sig value for knowledge of webtoon media was obtained, namely (0.000). so that statistically there is a significant difference before and after counseling with webtoon media.

This is in line with the research of Ni Ketut Ayu Wulandari, et al (2020) with the title Development of the Reproductive Health Education Comic Module on Increasing Adolescent Knowledge and Attitudes About the Impact of Premarital Sex at SMAN 2 Singaraja, Buleleng Regency, Bali Province which stated that there was a significant difference between the pretest knowledge scores. and posttest in the experimental group, so that the comic 
module is effective in increasing respondents' knowledge. This statement is reinforced by research conducted by Danaswari (2013) regarding teaching materials in the form of comic media which can significantly increase the mean score of students on test results by showing a pvalue $<0.01(p<0.05)$. The results for the pretest-posttest attitudes that have been carried out in the paired t test are obtained for a $\mathrm{p}$ value of $0.350(>0.05)$ so that statistically it can be concluded that there is no significant difference before and after the intervention through webtoon media.

Researchers assume that when counseling using the webtoon media takes place, the respondent only "knows" what he has got, but has not yet entered the "understanding" level, so the respondent is not able to apply it.

This is in accordance with the cone of experience by Edgar Dale who suggests understanding the role of the media in the process of getting a learning experience for students, namely being able to go through the process of doing or experiencing for yourself what is being learned, the process of observing and listening through certain media and the process of listening through language.
This is reinforced by the theory of Notoatmodjo (2011) which suggests that to obtain a supportive attitude, knowledge is not only needed, but is also influenced by emotional factors, personal experience, mass media, educational institutions, religious institutions, the influence of other people who are considered important, social and culture.

Differences in knowledge and attitudes of students about TRIAD KRR through Audio Visual and Webtoon media

From the results of the Man-Witney test conducted on the audio-visual and webtoon groups, it can be concluded that for knowledge there is no significant difference between the audio-visual and webtoon groups, but for attitudes there are significant differences between the audiovisual and webtoon groups.

In Rosmiyati's 2019 research with the research title How is the effect of health education using comics and video media on increasing knowledge in breast selfexamination (BSE) in adolescents at SMA Negeri 1 Cibingbin in 2019 says that there is no significant difference between the 2 groups of comics and videos, both comic and video media are both effective. 
According to the results of the evaluation of the reproductive health education information communication material (KIE KRR), the results show that respondents generally like pictorial stories both printed and audio-visual. Each media has its own segment according to the type of target (Sadiman, 2009).

Researchers (Rahmawati, 2016) said that a person's knowledge can be influenced by various factors such as economy, social relations, experience and exposure to mass media. Exposure to the mass media will get various information that can be accepted by the public, so that someone who is more frequently exposed to the mass media will get more information than someone who has never been exposed to mass media information.

In accordance with (Pocut Susila, 2015) said that the ease of obtaining information can help speed up a person to acquire new knowledge. can have a shortterm effect resulting in a change or increase in knowledge. The existence of new information about a matter provides a new cognitive foundation for the formation of knowledge about it.

\section{Conclusion}


basic threats to adolescent reproductive health.

\section{References}

Danaswari. (2013). Pengembangan Bahan Ajar Dalam Bentuk Media Komik Untuk Meningkatkan Hasil Belajar Siswa Kelas X SMAN 9 Cirebon Pada Pokok Bahasan Ekosistem. Jurnal Scientiae Educatia, 2(2).

Ernawati, H. (2018). Pengetahuan Kesehatan Reproduksi Remaja Di Daerah Pedesaan. Indonesian Journal for Health Sciences, 2(1), 58. https://doi.org/10.24269/ijhs.v2i1.820

Katharina, T., \& Yuliana, Y. (2018). Pengaruh Penyuluhan Kesehatan Reproduksi melalui Audio Visual dengan Hasil Pengetahuan Setelah Penyuluhan pada Remaja SMA Negeri 2 Pontianak Tahun 2017. Jurnal Kebidanan, 7, 47-54.

Kurniasari, L. (2017). Pengaruh Media Video Terhadap Pengetahuan Dalam Upaya Pencegahan Perilaku Seks Pranikah Pada Siswa Kelas VIII Di SMP Nuri Samarinda. In Ilmu Kesehatan Masyarakat Sekolah Tinggi Ilmu Kesehatan Muhammadiyah Samarinda.

Maolinda, N. et al. (2012). Hubungan Pengetahuan Dengan Sikap Siswa Terhadap Pendidikan Kesehatan Reproduksi Remaja di SMAN 1 Margahayu. Student e-Journal, 1, 3.

Nilasari, Y. (2019). pengaruh penyuluhan kesehatan reproduksi remaja dengan metode ceramah terhadap pengetahuan dan sikap pada siswa smkn 1 poncol kabupaten magetan. Stikes Bhakti Husada Mulia Madiun. http://repository.stikesbhm.ac.id/id/eprint/626

Notoatmodjo, S. (2011). Kesehatan
Masyarakat Ilmu dan Seni. Jakarta : Rineka Cipta.

Pocut, S. (2015). Faktor-Faktor Yang Berhubungan Dengan Pengetahuan Penggunaan Obat Generik Pada Masyarakat Di Wilayah Kerja Puskesmas Padang Panyang Kabupaten Nagan Raya Tahun 2015 (Vol. 151, Nomor 1). Universitas Teuku Umar.

Prabandari, A. W. (2018). Pengaruh Pemberian Penyuluhan Dengan Media Video Dan Booklet Terhadap Tingkat Pengetahuan Kesehatan Reproduksi Remaja Di Smk 2 Muhammadiyah Bantul. In Skripsi poltekkes Yogyakarta.

http://eprints.poltekkesjogja.ac.id/1675 /1/SKRIPSI .pdf

Rahmawati, F. (2016). Hubungan Pengetahuan Ibu, Pola Pemberian Makan, Dan Pendapatan Keluarga Terhadap Status Gizi Balita Di Desa Pajerukan Kecamatan Kalibagor Universitas Muhammadiyah Purwokerto. http://repository.ump.ac.id/id/eprint/83 9

Sadiman, et all. (2009). Media Pendidikan, Pengertian, Pengembangan, dan Pemanfaatannya. Jakarta : Rajawali Press.

Wulandari, N. K. A., Purnami, L. A., Rubaya, A. K., \& Kresnayana, M. Y. (2020). Pengembangan Modul Komik Pendidikan Kesehatan Reproduksi Terhadap Peningkatan Pengetahuan dan Sikap Remaja Tentang Dampak Seks Pranikah di SMA N 2 Singaraja Kabupaten Buleleng Provinsi Bali. Jurnal Kesehatan MIDWINERSLION, 5(1), 176-183. 